San Jose State University

SJSU ScholarWorks

Master's Theses

Master's Theses and Graduate Research

1995

\title{
The effects of vegetative reproduction on the recruitment and small scale distribution of the red alga Plocamium cartilagineum
}

James W. Downing

San Jose State University

Follow this and additional works at: https://scholarworks.sjsu.edu/etd_theses

\section{Recommended Citation}

Downing, James W., "The effects of vegetative reproduction on the recruitment and small scale distribution of the red alga Plocamium cartilagineum" (1995). Master's Theses. 1137.

DOI: https://doi.org/10.31979/etd.z8cu-4ds5

https://scholarworks.sjsu.edu/etd_theses/1137

This Thesis is brought to you for free and open access by the Master's Theses and Graduate Research at SJSU ScholarWorks. It has been accepted for inclusion in Master's Theses by an authorized administrator of SJSU ScholarWorks. For more information, please contact scholarworks@sjsu.edu. 


\section{INFORMATION TO USERS}

This manuscript has been reproduced from the microfilm master. UMI films the text directly from the original or copy submitted. Thus, some thesis and dissertation copies are in typewriter face, while others may be from any type of computer printer.

The quality of this reproduction is dependent upon the quality of the copy submitted. Broken or indistinct print, colored or poor quality illustrations and photographs, print bleedthrough, substandard margins, and improper alignment can adversely affect reproduction.

In the unlikely event that the author did not send UMI a complete manuscript and there are missing pages, these will be noted. Also, if unauthorized copyright material had to be removed, a note will indicate the deletion.

Oversize materials (e.g., maps, drawings, charts) are reproduced by sectioning the original, beginning at the upper left-hand corner and contimuing from left to right in equal sections with small overlaps. Each original is also photographed in one exposure and is included in reduced form at the back of the book.

Photographs included in the original manuscript have been reproduced xerographically in this copy. Higher quality $6^{n} \times 9^{n}$ black and white photographic prints are available for any photographs or illustrations appearing in this copy for an additional charge. Contact UMI directly to order.

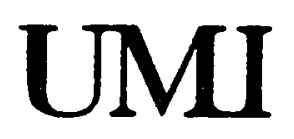




\title{
THE EFFECTS OF VEGETATIVE REPRODUCTION ON THE RECRUITMENT AND SMALL SCALE DISTRIBUTION OF THE RED ALGA PLOCAMIUM CARTILAGINEUM
}

\author{
A Thesis \\ Presented to \\ The Faculty of the Department of Biology \\ San Jose State University \\ In Partial Fulfillment \\ of the Requirements for the Degree \\ Master of Science
}

By

James W. Downing

December, 1995 
UMI Number : 1377228

UMI Microform 1377228

Copyright 1996, by UMI Company. All rights reserved.

This microform edition is protected against unauthorized copying under Title 17, United States Code.

\section{UMI}

300 North Zeeb Road

Ann Arbor, MI 48103 
() 1995

James Willis Downing

ALL RIGHTS RESERVED 
APPROVED FOR THE DEPARTMENT OF BIOLOGY

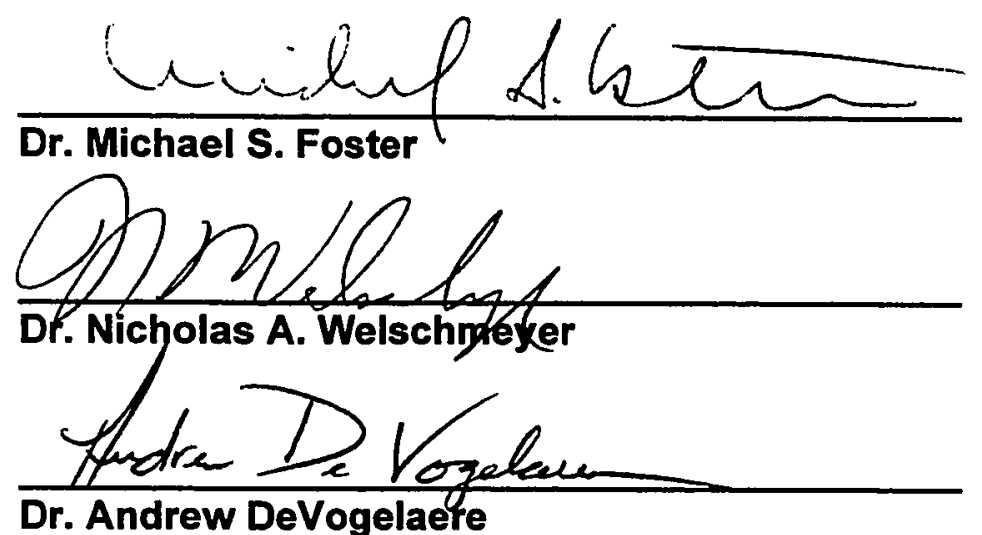

Dr. Andrew DeVogelaere

APPROVED FOR THE UNIVERSITY

Serene It. stanford 


\begin{abstract}
THE EFFECTS OF VEGETATIVE REPRODUCTION ON THE RECRUITMENT AND SMALL SCALE DISTRIBUTION OF THE RED ALGA PLOCAMIUM CARTILAGINEUM

by James W. Downing
\end{abstract}

\begin{abstract}
In the giant kelp forest at Stillwater Cove, Carmel Bay, California, the foliose red alga Plocamium cartilagineum (Linnaeus, Dixon) grows entangled with geniculate coralline algae. Plocamium was sampled periodically to compare phenology, morphology and plant size among three sites at different depths. Differences in recruitment of vegetative fragments in three subhabitat types at $15 \mathrm{~m}$ depth were tested experimentally. Plants at 15 and $30 \mathrm{~m}$ were less reproductive, weighed less, and produced hooked branches more often than those at the $2 \mathrm{~m}$ site. Tetrasporophytes dominated all sites. Enclosed fragments grew to adult size within four months in the field. Recruitment of Plocamium and Laurencia subopposita (another species that recruits via entanglement) to artificial substrates was greatest in open horizontal subhabitats and reduced beneath Pterygophora canopies and on vertical walls. Results suggest distribution and abundance of Plocamium in deep water are driven by vegetative reproduction.
\end{abstract}




\section{ACKNOWLEDGMENTS}

This work could not have been completed without the contribution of time, energy and thought from many people. My thesis committee members were invaluable in guiding my research and offering honest, objective criticism. I am especially indebted to Mike Foster for broadening my understanding of ecology and for keeping faith in me through times when I questioned my own resolve.

Support from fellow students was indispensable. Many people assisted in various ways, but I am especially grateful to Brenda Konar, Cassandra Roberts,

Ross Clark, George Leonard, Lawrence Honma, and Matt Edwards who not only contributed helpful advice and friendship, but sacrificed a great deal of body heat to the ocean in the name of my thesis.

My parents Willis and Mary Lou Downing provided unending support and encouragement through many emotional, financial and seismic ups and downs.

I am most grateful to my wife Rebecca who was courageous enough to insist that I persue this activity, and supported me in all ways through its completion.

This research was funded in part by a grant from the Earl and Ethel Meyers Oceanographic and Marine Biological Trust. 


\section{TABLE OF CONTENTS}

Abstract

Acknowledgements

Table of Contents

vi

List of Tables

vii

List of Figures

viii

Introduction

Methods

Site Description and Light Measurements 5

Phenology, Morphology and Biomass

Natural History

Fragment Viability

Recruitment

Results

Phenology, Morphology and Biomass

Natural History

Fragment Viability

Recruitment

Discussion

Literature Cited

Tables

Figures 


\section{LIST OF TABLES}

Table

Page

1 Two-Factor Analysis of Variance of the Number of

Reproductive Plocamium Plants per Transect.

$2 a \quad$ Two Factor Analysis of Variance of the Number of

Plocamium Plants per transect with the Hooked Morphology.

2b Two-Factor Analysis of Variance of Plocamium Dry Weight 26 per Plant.

2c Two-Factor Analysis of Variance of Longest Plant Length. 26

Type on the Recruitment of Fragments of Plocamium and Laurencia to Artificial Coralline Mimics.

Type on the frequency of permenant settlement of

Plocamium fragments to artificial coralline mats. 


\section{LIST OF FIGURES}

Figure

Page

$1 \quad$ Branching morphologies in Plocamium cartilagineum.

2

Proportion of each Plocamium sample grouped by degree of spore release.

3a Mean Number of Plants per Transect With the "Hooked" Morphology by Site and Date.

$3 b$ Mean Dry Weight by Site and Date.

3c Mean Longest Length by Date and Site.

4 Mean number of Plocamium and Laurencia fragment recruits for each interval by subhabitat type. 


\section{INTRODUCTION}

Studies on kelp forest ecology have been understandably focused on the large canopy forming species that dominate these areas (Dayton 1975, Deysher and Dean 1986, Reed and Foster 1984, Foster and Schiel 1985). Except for commercially important species, there has been little emphasis on the less conspicuous members of the algal assemblage. Found primarily in the understory, these species may be intimately linked to the organization of the community. Many invertebrates and fish use them as food, settlement substrata and spatial refugia (Coull and Wells 1983, Dearn 1987, Hacker and Steneck 1990, Pennings 1990a, Konar and Foster 1992). Knowledge of the processes governing the distribution and abundance of these understory species should enable a better understanding of the structure and dynamics of the system, as well as insights into the ecology of the algae themselves.

Reproduction and recruitment can have important effects on communities by structuring the initial distribution and abundance of organisms. Studies have repeatedly shown the importance of these "supply side" processes in various systems (Roughgarden et al. 1986, Reed et al. 1988, Underwood and Fairweather 1989, Fairweather 1991).

Many studies of the reproductive processes in marine macrophytes have been done in the laboratory where cultures have yielded information about post fertilization events, morphological differences between phases, fecundity, and responses to those physical factors easily isolated under controlled conditions. It is widely known, however, that red algae are capable of many types of reproduction besides those used to delineate ordinal relationships (Santelices 1992 for review). These reproductive mechanisms include parthenogenesis, 
androgenesis, apomeiosis, and various means of vegetative reproduction. Although the possible importance of alternate mechanisms of reproduction has long been stressed (Dixon 1964), studies evaluating their contribution to population dynamics and distribution in the wild are rare.

To understand the dynamics of macroalgal populations in nature, reproductive studies must relate to real systems. Marine algae are affected by a variety of environmental variables both physical and biotic. Many red algae seem to be quite plastic in their responses to these variables, making predictions based solely on laboratory observations of questionable ecological value.

Seasonal disturbances in central California kelp forests are well documented (Foster 1982, Cowen et al. 1982, Kimura and Foster 1984, Breda and Foster 1985, Harrold et al. 1988). The fluctuation in Macrocystis canopy cover is a regular event, with winter storms thinning the canopy to a minimum in late winter or early spring. Variation in the intensity of these disturbances may be great, however, making understory light, water motion, and sediment highly unpredictable. In such an environment, understory algae with the ability to withstand or respond to disturbance with rapid reproduction may be able to persist where others cannot (Sousa 1985, De Vogelaere 1991).

In Stillwater Cove, Carmel Bay, California, the understory assemblage of the giant kelp forest is dominated by articulated coralline algae and a few fleshy red algae (Reed and Foster 1984, Konar and Foster 1992). The two most common fleshy red algae, Plocamium cartilagineum (Linnaeus) Dixon and Laurencia subopposita (J. Agardh) Setchell, often occupy as much as 15 and 8 percent of the substrate respectively (Clark pers. com.). 
Plocamium cartilagineum (hereafter Plocamium) is widely distributed, occurring in the eastern Pacific from southeast Alaska to Chile, the western Mediterranean, the Canary Islands, Australia and New Zealand, Antarctica and the subantarctic islands, and in the eastern Atlantic from Norway to Senegal (Gabrielson and Scagel 1989, Abbott and Hollenberg 1976). In Stillwater Cove, it occurs from the low intertidal to over $30 \mathrm{~m}$ depth (pers. obs.). It is densely branched with a stoloniferous base that attaches to the substrate by small discs. These stolons perennate in many species of the genus while the main upright thallus may be prominent for only part of the year (Shepherd 1981). Plocamium typically has incurved terminal branchlets alternating with outcurved or hooked branches. Second or third order branches are often broken from the main axes. When growing vigorously, plants have a robust morphology with many incurved terminal ends and few hooks. Occasionally, however, the habit may be noticeably hooked and outcurved (Fig. 1). It has been described as a "shade loving" species that grows slowly and responds to environmental conditions rather than anticipating them (Kain 1987). Life history stages are isomorphic, with tetraspores usually produced in di- to trichotomously branched stichidia near the ends of higher order ramuli. Cystocarps commonly occur on the margins of axes of outer branches. Spermatia occur on the surface of outermost branchlets (Dixon 1967).

Laurencia subopposita (hereafter Laurencia) is epiphytic, with terminal ends that entwine around other highly branched algae and itself.

Tetrasporangia are borne on the terminal ends of shorter branchlets. Sexual plants are unknown in this species (Abbott and Hollenberg 1978) and it is observed to reproduce vegetatively by entwining fragments around other algae. 
In Stillwater Cove it is found entangled with geniculate coralline and other coarse algae from the low intertidal to over $20 \mathrm{~m}$ depth. The distribution of Laurencia and Plocamium in the subtidal areas of Stillwater Cove is not uniform; both are rare under the subsurface canopy of the kelp Pterygophora californica and on vertical walls (pers. obs.).

Although both of these algae are considered epiphytic, neither penetrates the host nor support plant. They are more aptly described as entangled free living forms. Such species often reproduce vegetatively especially in calm waters (Norton and Mathieson 1983).

The questions addressed in this study are:

1. What are the natural history traits of Plocamium relative to other vegetatively reproducing species?

2. Are fragments abscised by Plocamium viable agents of vegetative reproduction?

3. What is the contribution of fragments and spores to reproduction of Laurencia and Plocamium in Stillwater Cove?

4. What are the consequences of these modes of reproduction for the temporal and spatial distribution of Plocamium and Laurencia? 


\section{Methods}

\section{Site Description and Light Measurements}

The study was done in Stillwater Cove, a south facing portion of Carmel Bay in Monterey County, California (36 $\left.34^{\prime} \mathrm{N}, 121^{\circ} 56^{\prime} \mathrm{W}\right)$. The cove is protected from prevailing northwesterly swell, but occasionally experiences moderate to heavy waves from the west and south. Study sites included three for collection, one each at 2, 15 and $30 \mathrm{~m}$ depth, and two near the $15 \mathrm{~m}$ collection site where experimental manipulations were done.

The $2 \mathrm{~m}$ site had a dense benthic assemblage of various macrophytes, especially Gastroclonium coulteri, Prionitis lanceolata, Gigartina corymbifera, Plocamium cartilagineum, various species of Laurencia, and geniculate coralline algae, and experienced occasional shading from adjacent Macrocystis. The $15 \mathrm{~m}$ site was within the main Macrocystis canopy that covers much of the cove. It had a patchy subsurface canopy of Pterygophora californica, and an understory assemblage dominated by articulated coralline algae, Plocamium, and Laurencia. The $30 \mathrm{~m}$ site had no surface or subsurface canopy and a benthic algal assemblage of a few geniculate coralline algae and Plocamium.

Light (PAR) measured with a Licor ${ }^{\circledR}$ meter with a cosine collector was $20 \%$ of surface irradiance at the $2 \mathrm{~m}$ site, while the $15 \mathrm{~m}$ and $30 \mathrm{~m}$ sites received $2.7 \%$ and $1.6 \%$ respectively. These measurements, made within 2 hours of midday on June 12,1992, agree well with light measurements from nearby areas of Stillwater Cove made on other dates (Roberts, pers. com.). 


\section{Phenology, Morphology, and Biomass}

To measure changes in population size structure, reproductive phenology, developmental state of reproductive structures, and morphology, thirty Plocamium plants were selected at random each month from a $20 \times 20 \mathrm{~m}$ square area at $15 \mathrm{~m}$ depth. A twenty meter tape was placed at three randomly selected distances along one axis of the area and the closest Plocamium plant to ten random points along each tape was collected. Quarterly samples were collected in an identical fashion from the $2 \mathrm{~m}$ site and $30 \mathrm{~m}$ site. The more frequent sampling at the $15 \mathrm{~m}$ site was designed to provide information about the reproductive condition of the plants for recruitment experiments near the collection site.

The complex branching habit made identification of distinct individuals difficult, so all plants were traced to individual stolon complexes before collection. If the individuality of the plant was unclear, the next closest plant was taken. Collected plants were examined under a dissecting scope at 40X. Fertile tetrasporic individuals were grouped by degree of spore release. These groups were: non reproductive, immature stichidia with no pigmented tetraspores visible, stichidia with less than $50 \%$ of spores released, 50 to $75 \%$ released, and greater than $75 \%$ released. Cystocarpic plants were ranked by the size of the cystocarps and full or empty, since the structures tended to release their contents all at once. The classes for cystocarpic plants were: not reproductive, cystocarps just emergent as small bumps, fully formed to $1 \mathrm{~mm}$, unreleased larger than $1 \mathrm{~mm}$, and empty or released. The presence or absence of the hooked morphology on any part of the plant was recorded for each individual. In addition, associated invertebrates and epiphytic algae were noted. The mean 
number of hooked plants per transect at each site on each quarterly collection date was analyzed with a two way analysis of variance followed by a Tukey multiple comparison test. After examination, each plant was weighed wet and then dried at 60 degrees $\mathrm{C}$ for 48 hours or until no weight change was evident. Mean dry weight was compared between quarterly collection dates and sites with a two way analysis of variance followed by a Tukey multiple comparison test.

Natural History

Natural history information on growth habit, fragmentation mechanisms, epiphytes and associated fauna was collected on periodic surveys using SCUBA. These observations were made in various areas in the cove at around $15 \mathrm{~m}$ depth. Haphazardly selected plants were examined closely by eye to identify invertebrates, fish, epiphytes and parasites. Other general observations were made on collection dives and from collected samples.

Initial information on the distribution of Plocamium was obtained by placing a random point quadrat with a $1 \mathrm{~m}$ bar (Foster 1975, Leonard and Clark 1994 ) in and around the $15 \mathrm{~m}$ collection site. Quadrats were placed by swimming in random compass directions for random numbers of kicks and tossing the quadrat backwards after the last kick. Forty quadrats of ten points each were sampled to estimate percent cover and attachment substratum. The occurrence of Plocamium on coralline mat, crustose coralline or rock substrate versus availability of these substrata was compared using Chi square. The total percent cover of Plocamium was multiplied by the proportion of each substrate to determine the expected value 


\section{Fragment Viability}

To test fragment viability, the water next to a number of Plocamium plants was disturbed by gently fanning by hand. Those fragments that separated from the main plant were collected with a hand net. One fragment was placed in each of five plastic $1 \mathrm{~cm}$ mesh envelopes. The envelopes were spaced 3 to $5 \mathrm{~m}$ apart and nailed to the substrate with concrete nails in areas with no Pterygophora canopy at $15 \mathrm{~m}$ depth. These were set out in August 1991 and measured the following November and February.

\section{Recruitment}

The hypothesis that recruitment of Plocamium and Laurencia fragments differed between open horizontal, vertical, and Pterygophora shaded subhabitat types and between different time intervals was tested using artificial substrata that mimicked coralline mats. Natural corallines could not be used because of the difficulty of creating plots that were spatially similar and the possibility that previously settled propagules might confound results. Substrates were made of

Enkamat ${ }^{\circledR}$, a matrix of plastic fibers that intertwine loosely and irregularly, forming a mat approximately three centimeters thick. Upright parts of coralline mats that sometimes trap fragments were simulated by attaching six $3 \times 8 \mathrm{~cm}$ strips of the plastic mat in an upright orientation to each $.5 \times .5 \mathrm{~m}$ square.

Geniculate coralline branches, Plocamium, and Laurencia were cleared from ten $1 / 4 \mathrm{~m}^{2}$ plots in each subhabitat type at two sites separated by approximately $250 \mathrm{~m}$. Plot sites were selected within areas of each subhabitat type so that Plocamium plants were no more than $1 / 2 \mathrm{~m}$ away and to avoid obstacles that would prohibit attachment of the mats. Half the plots were covered 
with artificial coralline substrates and the other half were left uncovered to test for the difference in recruitment between areas with and without artificial substrates. Recruits were counted at the end of four three month intervals. Corallines, Plocamium, and Laurencia that resprouted or recruited were removed between intervals. At the end of each interval, the total number of recruits on all plots, both artificial and cleared only, was recorded. The artificial substrates were then removed, soaked in $10 \% \mathrm{HCl}$ for $\mathbf{4 8}$ hours and sprayed with water to remove any encrusting organisms and placed back in the field.

Unusually strong southwest storms in the winter of 1992/93 sent swells more directly into Stillwater Cove, dislodging many of the mats. Data from that interval were omitted. Some experimental replicates were also lost during other intervals creating unequal sample sizes requiring subsequent analytical modifications.

Variances among the Plocamium fragment data were unequal, so a root $x+3 / 8$ transformation was applied and resulted in homogeneity. After finding no significant site effect using a T-test $(p=0.299)$, the data were pooled between the two sites. Cleared plots were also removed from the analysis because there was almost no recruitment to these treatments. The mean number of Plocamium fragments for each of the remaining intervals and treatments was analyzed with a two-way analysis of variance. Data for Laurencia recruitment were analyzed in an identical manner to those for Plocamium except that transformation was unnecessary.

During the summer interval, an estimate of recruitment success was obtained by mapping, measuring, and sketching settled fragments weekly. The gain and loss of the fragments were recorded by dividing the plots into quarters 
and noting whether particular fragments had remained. Any movements more distant than within the same quarter were treated as loss and new recruitment events. Mapping and sketching was judged effective because recruitment in previous intervals was low and variation in fragment size and shape was great. It was therefore unlikely that a fragment of the same dimensions would settle on the same spot vacated by another. Recruitment success or permanence was estimated by dividing the number of recruits remaining at the end of the interval by the gross number of settlements on that plot. The data were arcsine transformed to achieve normality and analyzed with a one-way analysis of variance, followed by a Tukey multiple comparison test.

To test for the contribution of spores to recruitment of Plocamium and Laurencia, substrates free of any preexisting Plocamium spores were needed. Thirty concrete settling blocks were placed in groups of three as close together as topography permitted in the open treatment areas at both sites in September 1992. The total surface area of each set of three was equivalent to that of one artificial coralline mat. The blocks were recovered in August 1993. The entire surface of each block was examined under a dissecting scope to count recruits. All species of recruited algae were identified according to Abbott and Hollenberg (1987). Recruitment of Plocamium and Laurencia was compared to the total number of settled fragments on the experimental and control plots for the open treatment areas summed over the whole experiment. 


\section{Results}

\section{Phenology, Morphology and Biomass}

Differences in reproductive phenology among the three sites were distinct. All reproductive individuals found at both the 15 and $30 \mathrm{~m}$ sites were tetrasporophytes. Approximately ten percent of the reproductive Plocamium plants at the $2 \mathrm{~m}$ site were cystocarpic (Fig.2). Male plants were never found. There were more reproductive individuals at the $2 \mathrm{~m}$ site (Table 1) and the tetrasporangial stichidia on the plants there were usually larger and more robust than those at either of the other two sites. There were usually reproductive Plocamium plants at all three main collection sites with the exception of December 1992 at 15 and 30m. Reproductive plants were always present in the shallow collections although their abundance varied. Reproductive structures on plants at the $2 \mathrm{~m}$ site tended to be more developed than those at either the 15 or $30 \mathrm{~m}$ sites. In general, tetraspores were produced all year with peaks in late spring and early summer.

There was a distinct difference in the number of plants with hooked branches. The $30 \mathrm{~m}$ site had the most (often 80 to $90 \%$ ) and the $2 \mathrm{~m}$ site the least (seldom more than $\mathbf{2 0 \%}$ ). A significant interaction effect was found between date and site (Table 2a). There were usually significant differences between the $2 \mathrm{~m}$ and $30 \mathrm{~m}$ sites. Plants at the $15 \mathrm{~m}$ site tended to be more hooked than the shallow site when dry weight was high (summarized Fig. 3a,b). Nearly all Plocamium fragments observed possessed the hooked morphology to some degree.

Presence of reproductive structures (Fig. 2), mean dry weight (Fig. 3b), and maximum length (Fig. 3c) began dropping sharply in fall of 1992 and 
continued to a minimum in December 1992. Dry weight remained low at all sites until the spring of 1993 when plants at the $2 \mathrm{~m}$ and $15 \mathrm{~m}$ sites began to regrow between March and April. The $30 \mathrm{~m}$ site did not begin to increase again until after the April collection. By July, mean dry weight at the two deeper sites had reached levels comparable to those of the previous summer. The $2 \mathrm{~m}$ site continued to increase until October, when dry weight values approached those before the decline.

Plants at the $2 \mathrm{~m}$ site were generally much larger and more complex in their branching habit than those at either the 15 or $30 \mathrm{~m}$ sites; however, significant interaction terms between site and date required comparison between individual means for dry weight, and longest length (Table $2 b, c)$. Over all, plants at the $2 \mathrm{~m}$ site averaged $2.9 \mathrm{~g}$ dry weight while those at the 15 and $30 \mathrm{~m}$ sites averaged 1.0 and $0.8 \mathrm{~g}$, respectively (Fig. $3 \mathrm{~b}$ ). Differences in dry weight between the two deeper sites and the shallow site were usually significant, while differences between the $15 \mathrm{~m}$ and $30 \mathrm{~m}$ sites were not. Although presence of reproductive structures, dry weight, and morphology often varied between sites, longest plant length remained similar (Fig. 3c).

\section{Natural History}

Larger Plocamium plants were often epiphytized by crustose coralline algae, thin fleshy red crusts, and diatoms. Smaller plants tended to be less heavily covered. Many types of invertebrates, especially gamarrid and caprellid amphipods, were often found on the plants. In the spring of 1992 newly settled Aplysia were abundant on Plocamium plants with as many as ten small $(1-4 \mathrm{~cm})$ individuals per plant. As these animals grew, they consumed Plocamium almost 
exclusively until animals became rare in January or February of the following year. Aplysia were not observed in comparable numbers in either the year before or after.

The occurrence of Plocamium on geniculate corallines at $15 \mathrm{~m}$ depth was greater than would be expected from random settlement $\left(X^{2}=171.4_{39}, P<<0.05\right)$. Collected plants were nearly always entangled basally with geniculate corallines at the two deepest sites and with a number of calcified and fleshy algae at the shallow site.

Plocamium plants were often observed with abscised branches due to drag, "tumbleweeding," and "leapfrogging." Breakage from drag occurred when water motion across the thallus of the plant was strong enough to break off fragments. "Leapfrogging" was the bending of the plant by water motion to the point where the upper branches contacted the substrate. The branchlets then became entangled in the adjacent substrate and were torn free of the main plant. "Tumbleweeding" was similar to the previous mechanism but these plants became completely dislodged from the substrate and then repeatedly entangled with and broke free from adjacent corallines as they tumbled, leaving fragments behind. Although it was not directly observed, abrasion from Pterygophora blades may also have contributed to breakage. Plants under the Pterygophora canopy often had many broken branches, sometimes to the point of complete erosion to the main axes.

\section{Fragment Viability}

Four of the five fragments used to test viability survived and grew to adult size. The initial mean fragment size in September 1991 was $5.1 \mathrm{~cm}$. By 
November 1991 the mean longest length had increased to $8.0 \mathrm{~cm}$, and in January it reached $12.3 \mathrm{~cm}$. By this time many uprights were growing through the mesh with stolons spreading across the substrate. The fifth fragment was covered by shifting sediment and did not survive.

\section{Recruitment}

Open subhabitats always had the greatest number of Plocamium and recruits (Fig. 4). Vertical and Pterygophora treatments usually had less. Differences between subhabitats were all significant. Differences in the number of Plocamium fragment recruits were significant (Table 3). Laurencia recruitment was only significantly different between subhabitats.

Movements of settled fragments within the same experimental plot happened only twice. The frequency of permanent settlement was highest in open treatments followed by Pterygophora and vertical subhabitats. Fragments of Plocamium remained over 1.5x more often in open treatment areas than in the Pterygophora treatments and over $5 \times$ more often than in vertical subhabitats. No significant site effect was found. Differences between subhabitat types were all significant (Table 4).

Settling blocks recovered at the end of the experiment had a luxuriant growth of algae that covered nearly the entire surface of each block. Nongeniculate and geniculate coralline algae were the most common colonizers, followed by a number of unidentified non-coralline red crusts. Although many foliose noncalcified algal species recruited to the blocks, Plocamium and Laurencia did not. 


\section{DISCUSSION}

Reproductive phase imbalances such as those observed in Plocamium are common among the red algae (Dixon 1973). Tetrasporophytes prevail in other localities, but the small scale distribution patterns of the reproductive phases are not constant. In the Isle of Man, for example, the proportion of gametophytes increases with depth (Kain 1986). This is in direct contrast to the pattern of distribution in Stillwater Cove, where carposporic plants were found only at the $2 \mathrm{~m}$ site (Fig. 2).

Another curious observation is the lack of male gametophytes. Although male reproductive structures are more cryptic than tetrasporangial stichidia or cysotcarps, it is unlikely that misidentification was responsible for the observed absence of male plants. In March of 1992 at the peak of reproduction, all the plants at the $2 \mathrm{~m}$ site were reproductive, and all were either tetrasporic or carposporic. In October 1993, almost $90 \%$ of the plants from the shallow site were reproductive, but none were male. Lack of male gametophytes has often been reported, but with few explanations (Dixon 1973). In Stillwater Cove, male plants may be present in a nearby area, have a short period of reproduction, or they may indeed be absent. The latter case would require some form of apomixis by the female plants, another occasional phenomenon in red algae (Hawkes 1990 for review).

Plocamium produces spores the entire year in Stillwater Cove with slight peaks in spring and summer. Plants that were large enough were always reproductive. Since no recruitment from spores was observed, and all the individuals at the two deeper sites were tetrasporic, the fate of the spores is 
unknown. The year over which the recruitment experiment was done may be anomalous, however. Since the production of spores dropped sharply in October of 1992 (Fig. 2), and remained low until June of the following year, 1992/93 may have been a year of lower than normal spore production. By July of 1993, however, spore production had rebounded to previous levels, and still no spore recruitment was found.

The physical environment was similar in many respects between the $15 \mathrm{~m}$ and $30 \mathrm{~m}$ sites. Both sites experienced similar low light levels, but fluctuation of the kelp canopies at the $15 \mathrm{~m}$ site may change this condition periodically. Since there were no surface or subsurface canopies at the $30 \mathrm{~m}$ site, the light levels there were presumably more constant.

Many species of invertebrates were found associated with Plocamium, but none seemed to affect it except Aplysia. These opisthobranch mollusks are known to settle on Plocamium and Laurencia almost exclusively (Carefoot 1978, Pennings 1990) and accumulate terpenes from the algae. Given the large numbers of these animals that recruited to and grazed on the plants, it is likely that they were at least partially responsible for the sharp decline in biomass in the fall and winter of 1992. Since this event was coincident with unusually strong winter storms, effects of the two were confounded. The previous and subsequent winters had declines in biomass, but neither was as extreme as that in 1992. Winter storms were comparatively mild and Aplysia recruitment low in previous and subsequent years (Clark, pers. com.).

Plocamium plants were not grazed or battered to the point that they disappeared entirely. The average length at the minimum in the winter of 1992 was roughly comparable to the thickness of the coralline mat. The geniculate 
corallines may therefore provide a refuge from grazing, battering by water motion, or both.

Disturbance from large swells may account for much of the fragmentation and dispersal of Plocamium. Indeed, in the winter of 1991/92, even the geniculate corallines themselves were often broken from their attachment points. These storms, while a potential cause of breakage and dispersal, also hinder direct observation of the processes. Thus, winter storms may contribute greatly to the process of vegetative reproduction, but estimation of the magnitude of this effect is difficult.

Vegetative reproduction can have dramatic effects on the success of any species in a local area. Some of the advantages of this mode of reproduction are more competent, longer lived propagules, successful reproduction under conditions unfavorable for spores, magnification of successful traits in progeny, and the ability to exploit spatial resources regardless of seasonal constraints that often govern spore production (Silander 1985, Williams 1975.)

Reproduction from fragments is common among all three divisions of marine macrophytes (Norton and Mathieson 1983). Fragments as small as a few cells have been cultured in the laboratory, suggesting little need for substantial propagules. Fragments have proved viable in culture even after digestion by grazers (Santelices and Ugarte 1987). Presumably, however, larger fragments are more competent than smaller ones, and Plocamium and Laurencia produce comparatively large fragments. The average size of colonizing fragments of Plocamium was well over five centimeters.

The lack of recruitment to settling blocks and control plots is additional strong evidence that recruitment of Plocamium and Laurencia at this site in 
Stillwater Cove occurs nearly exclusively by vegetative fragmentation or spreading stolons. Recruitment by spores may occur at shallower depths, as suggested by the presence of female gametophytes at the $2 \mathrm{~m}$ collection site.

Assuming typical survivorship is as high as that observed when fragments were enclosed in the mesh envelopes, and given the lack of recruitment on blocks, fragmentation and vegetative growth are potentially the major sources of Plocamium and Laurencia recruitment at this site. Successful attachment varies greatly between subhabitats, however. Fragments in Pterygophora and vertical subhabitats have both low settlement rates and low survivorship. It is likely that fragments simply fall to lower areas (usually sand and cobble channels in Stillwater Cove) if they land on vertical walls. In Pterygophora subhabitats, gravity works to the advantage of settling fragments, but reduced light levels may slow the rate of attachment. Kain (1987) found that growth rates of Plocamium were reduced under Laminarian canopies. Fragments may therefore take longer to grow attachments beneath Pterygophora canopies. In addition, there may be increased sedimentation related to reduced flow within the understory canopy area (Eckman et al. 1989). These factors may affect the ability of Plocamium to settle and attach permanently. Open horizontal areas have none of these problems.

Both Plocamium and Laurencia possess morphological characteristics that enhance the probability of fragments settling on such substrate. The twining habit in Laurencia and the hooked morphology of Plocamium are both facilitate entanglement with coralline algae. Hooked or twining morphologies, reduced fertility, and reproductive phase imbalances are all common traits among other vegetatively reproducing species (Norton and Mathieson 1983). 
It seems clear that both Plocamium cartilagineum and Laurencia subopposita reproduce vegetatively in Stillwater Cove at deeper depths. The commonness of these two species may be due to many factors including the availability of appropriate substrate and the ability to tolerate low light levels. In an environment that can be highly variable with respect to any physical factor, a species with the ability to respond in a number of ways has a distinct advantage (Shepherd, 1981). Plocamium seems well equipped for the variability in physical factors it experienced in Stillwater Cove. It is usually producing spores but retains the ability to reproduce vegetatively by various means. Creeping stolons can produce new uprights when water motion is low. If water motion is high, it can fragment in a number of ways and disperse propagules that have a high probability of success even in areas with low light.

Recruitment and the resultant small scale distribution patterns of Plocamium and Laurencia at the $15 \mathrm{~m}$ site are also clearly fragment driven. The complete lack of individuals growing from spores, the characteristic morphological and reproductive patterns, and the success of fragment recruitment to artificial coralline substrates in different subhabitats all support this conclusion. Moreover, it is likely that the same mechanisms are operating at the $30 \mathrm{~m}$ site. The plants there had lower levels of tetraspore production, the hooked morphology was more frequent, and gametophytes were also absent.

Reproduction mechanisms of Plocamium at the $2 \mathrm{~m}$ site may be various. Although no males were found at the site, they may have been present in nearby unsampled areas or in small numbers for short periods of time such that they were missed by the quarterly sampling. It is possible, however, that vegetative reproduction contributes significantly to plants at this depth as well. Although 
plants were usually more reproductive and produced fewer hooked branches, they were still found entangled with other complex algae, and produced many hooks from time to time.

Regardless of subhabitat type, however, Plocamium and Laurencia recruited more successfully in spatially complex environments as those created by the coralline mat. Both possess classic adaptations for entangling with complex structure on the bottom. In Stillwater Cove, the establishment of a coralline mat may be perquisite to colonization of these species, a condition similar to that needed for attachment of Phyllospadix seeds in the intertidal (Turner 1983).

Vegetative reproduction can have significant consequences to a plant's success in various habitats. Certainly if a species retains its ability to reproduce vegetatively or from spores, the added flexibility presents the potential to succeed in a wider range of habitats. In the case of Plocamium, it's nearly world wide geographic distribution and intertidal to deep subtidal depth distribution may be the result of such flexibility. 


\section{LITERATURE CITED}

Abbott, I.A. \& Hollenberg, G.J. 1976 Marine Algae of California. Stanford University Press, Stanford, CA. 827 pp.

Breda, V.A. \& M.S. Foster. 1985. Composition, abundance and phenology of foliose red algae associated with two central California kelp forests. $J$. Exp. Mar. Biol. Ecol. 94:115-130.

Carefoot, T.H. 1987. Aplysia: its biology and ecology. Oceanogr. Mar. Biol. Annu. Rev. 25:176-284.

Coull, B.C. \& J.B.J. Wells. 1983. Refuges from fish predation: Experiments with phytal meiofauna from the New Zealand rocky intertidal. Ecology 64:1599-1609.

Cowen, R.K., C.R. Agegian, \& M.S. Foster. 1982. The maintenance of community structure in a central California giant kelp forest. J. Exp. Mar. Biol. Ecol. 64:189-201.

Dayton, P.K. 1975. Experimental studies of algal canopy interactions in a sea otter-dominated kelp community at Amchitka Island, Alaska. U.S. Natl. Mar. Fish. Serv. Fish. Bull. 73:230-237.

Dearn, S.L. 1987. The fauna of subtidal articulated coralline mats: composition, dynamics, and effects of spatial heterogeneity. M.Sc. Thesis, California State University, Stanislaus. 51 pp.

De Vogelaere, A.P. 1991. Disturbance, succession and distribgution patterns in rocky intertidal communities of central California. PhD Dissertation, University of California Santa Cruz. 136 pp.

Deysher, L., \& T.A. Dean. 1986. In situ recruitment of sporophytes of the giant kelp, Macrocystis pyrifera (L.) C.A. Agardh: effects of physical factors. J. Exp. Mar. Biol. Ecol. 103:41-63.

Dixon, P.S. 1964. Perennation, vegetative propagation and algal life histories, with special reference to Asparagopsis and other rhodophyta. $\ln \mathrm{T}$. Levring, [Ed.]. Proceedings of the fifth marine biological symposium. Botanica Gothoburgensia III. pp. 67-74.

Dixon, P.S. 1967. The typification of Fucus cartilaglneus and F. corneus Huds. Blumea, 15:55-62. 
Dixon, P.S. 1973. Biology of the Rhodophyta. Otto Koeltz Science Publishers, Koenigstein. 285 pp.

Eckman, J.E., D.O. Duggins, \& A.T. Sewell. 1989. Ecology of understory kelp environments. I. Effects of kelps on flow and particle transport near the bottom. J. Exp. Mar Biol. Ecol. 129: 173-187.

Fairweather, P.G. 1991. Implications of "supply-side" ecology for environmental assessment and management. Trends Ecol. Evol. 6:60-63.

Foster, M.S. 1975. Regulation of algal community development in a Macrocystis pyrifera forest. Mar. Biol. (Berl.) 32:331-342.

Foster, M.S. 1982. The regulation of macroalgal associations in kelp forests. In L. Srivastava, [Ed.]. Synthetic and degradative processes in marine macrophytes. Walter de Gruyter, Berlin, pp. 185-205.

Foster, M.S. \& D.R. Schiel. 1985. The ecology of giant kelp forests in California: a community profile. U.S. Fish Wildl. Serv. Biol. Rep. 85(7.2), $152 \mathrm{pp}$.

Gabrielson, P.W. \& R.F. Scagel. 1989. The marine algae of British Columbia, northern Washington and southeast Alaska: division Rhodophyta (red algae), class Rhodophyceae, order Gigartinales, families Caulacanthaceae and Plocamiaceae. Can. J. Bot. 67:1221-1234.

Hacker, S.D. \& R.S. Steneck. 1990. Habitat architecture and the abundance and body-size-dependent habitat selection of a phytal amphipod. Ecology 71:2269-2285.

Harrold, C., J. Watanabe, \& S. Lisin. 1988. Spatial variation in the structure of kelp forest communities along a wave exposure gradient. P.N.Z.I. Mar. Ecol. 67:65-77.

Hawkes, M.W. 1990. Reproductive Strategies. In K.M. Cole \& R.G. Sheath, [Eds.]. Biology of the Red Algae. Cambridge University Press, New York, pp. $455-476$

Kain, J.M. 1986. Plant size and reproductive phenology of six species of Rhodophyta in subtidal Isle of Man. Br. phycol J. 21:129-138. 
Kain, J.M. 1987. Seasonal growth and photoinhibition in Plocamium cartilagineum (Rhodophyta) off the Isle of Man. Phycologia 26:88-99.

Kimura, R.S. \& M.S. Foster. 1984. The effects of harvesting Macrocystis pyrifera on the algal assemblage in a giant kelp forest. Hydorbiologia. 116/117:425-428.

Konar, B. \& M.S. Foster. 1992. Distribution and recruitment of subtidal geniculate coralline algae. J. Phycol. 28:273-280.

Leonard, G. H. \& R.P. Clark, 1993. Point quadrat versus video transect estimates of the cover of benthic red algae. Mar. Ecol. Prog. Ser. 101:203-208.

Norton, T.A. \& A.C. Mathieson. 1983. The biology of unattached seaweeds. In Round \& Chapman, [Eds.] Progress in phycological research, vol. 2. Elsevier Science Publishers, B.V, pp. 333-386.

Pennings, S.C. 1990a. Multiple factors promoting narrow host range in the sea hare Aplysia californica. Oecologia 82:192-200.

Pennings, S.C. 1990b. Preditor-prey interactions in opisthobranch gastropods: effects of prey body size and habitat complexity. Mar. Ecol. Prog. Ser. 62:95-101.

Pennings, S.C. 1990c. Size-related shifts in herbivory: specializations in the sea hare Aplysia californica Cooper. J. Exp. Mar. Biol. Ecol. 142:43-61.

Reed, D.C. \& M.S. Foster. 1984. The effects of canopy shading on algal recruitment and growth in a giant kelp forest. Ecology. 65:937-948.

Reed, D.C., D.R. Laur, \& A.W. Ebling. 1988. Variation in algal dispersal and recruitment: The importance of episodic events. Ecol. Monog. 58:321335.

Roughgarden, J., S.D. Gaines, \& S.W. Pacala. 1986. Supply side ecology: The role of physical transport processes. In J.R.H. Gee \& P.S. Giller, [Eds.]. Organization of communities past and present. Blackwell Scientific Publications, Oxford, pp. 491-518.

Santelices, B. 1990. Patterns of reproduction, dispersal and recruitment in seaweeds. Oceanogr. Mar. Biol. Annu. Rev. 28:177-276. 
Santelices, B. \& R. Ugarte. 1987. Algal life-history strategies and resistance to digestion. Mar. Ecol. Prog. Ser. 35:267-275.

Shepherd, S.A. 1981. Ecological strategies in a deep water red algal community. Bot. Mar. 24:475-463.

Silander, J.A. Jr. 1985. Microevolution in clonal plants.. In J.B.C. Jackson, L.W. Buss, \& R.E. Cook, [Eds]. Population Biology and Evolution of Clonal Organisms. Yale University Press pp. 107-152.

Sousa, W.P. 1985. Disturbance and patch dynamics on rocky intertidal shores. In S.T.A. Pickett and P.S. White [Eds.] The Ecology of Natural Disturbance and Patch Dynamics. Academic Press, New York, pp. 101124.

Turner, T. 1983. Facilitation as a successional mechanism in a rocky intertidal community. Am. Nat. 121:729-738

Underwood, A.J. \& P.G. Fairweather. 1989. Supply-side ecology and benthic marine assemblages. Trends Ecol. Evol. 4: 16-20.

Williams, G.C. 1975. Sex and evolution. Princeton Univ. Press, Princeton N.J. $200 \mathrm{pp}$. 
Table 1. Two factor analysis of variance of the number of reproductive Plocamium plants per transect. The effects of site and date were tested $(p<0.05)$. Tukey pairwise comparisons were run for site and date. 


\begin{tabular}{ccccc}
\hline SOURCE & DF & MS & F-ratio & P \\
\hline SITE & 2 & 66.475 & 22.429 & $<0.001$ \\
DATE & 8 & 56.003 & 18.901 & $<0.001$ \\
SITE*DATE & 16 & 4.151 & 1.401 & n.s. \\
ERROR & 54 & 2.963 & &
\end{tabular}

Tukey Multiple comparison results:

Differences between sites $(2 \mathrm{~m}, 15 \mathrm{~m}$, and $30 \mathrm{~m})$ were all significant $(p<0.05)$.

Differences between underlined dates were not significantly different.

Dec '91 Feb '92 May '92 Aug ‘92 Dec '92 Apr ‘93 Jul'93 Oct ‘93 Jan ‘94

$\longrightarrow \quad-$


Table 2. Two factor analyses of variance for the effects of date and site on the number of hooked Plocamium plants per transect (A), dry weight per plant (B), and longest plant length $(C)$. Significant interaction effects required comparisons of individual means. Summary of Tukey pairwise comparisons are shown on figure $3 a, b$, and $c$. 
A: Hooked

plants per

transect

SOURCE O

VARIATION

DATE

SITE

488.2

\begin{tabular}{cccc} 
DF & MS & F-RATIO & P \\
\hline 8 & 22.9 & 25.4 & $<0.00$ \\
2 & 244.1 & 270.9 & $\begin{array}{c}1 \\
\end{array}$ \\
16 & 10.1 & 11.2 & $<0$ \\
54 & 0.9 & & 1 \\
& & & 1 \\
\hline
\end{tabular}

DATE*SITE

162.0

16

48.7

54

B: Dry Weight

\begin{tabular}{cccccc}
\hline $\begin{array}{c}\text { SOURCE OF } \\
\text { VARIATION }\end{array}$ & SS & DF & MS & F-RATIO & P \\
\hline DATE & 552.5 & 7 & 78.9 & 30.7 & $<0.00$ \\
SITE & 587.0 & 2 & 293.5 & 114.3 & $<0.00$ \\
& & & & & 1 \\
DATE*SITE & 348.6 & 14 & 24. & 9.7 & $<0.00$ \\
ERROR & 1786.7 & 696 & 2.6 & & 1 \\
\hline
\end{tabular}

C: Maximum

Length

\begin{tabular}{|c|c|c|c|c|c|}
\hline $\begin{array}{l}\text { SOURCE OF } \\
\text { VARIATION }\end{array}$ & SS & DF & MS & F-RATIO & $\mathbf{P}$ \\
\hline DATE & $\begin{array}{c}11623 . \\
5\end{array}$ & 7 & $\begin{array}{c}1660 . \\
5\end{array}$ & 92.6 & $\begin{array}{c}<0.00 \\
1\end{array}$ \\
\hline SITE & 513.2 & 2 & 256.6 & 14.3 & $\begin{array}{c}<0.00 \\
1\end{array}$ \\
\hline DATE*SITE & 1134.3 & 14 & 81.0 & 4.5 & $\begin{array}{c}<0.00 \\
1\end{array}$ \\
\hline ERROR & $\begin{array}{c}12479 . \\
1\end{array}$ & 696 & 17.9 & & \\
\hline
\end{tabular}


Table 3. Analyses of variance for the effects of date and subhabitat type on the recruitment of fragments of Plocamium and Laurencia to artificial coralline mimics. Underlined dates and subhabitats are not significantly different $(p>0.05)$ as determined by Tukey multiple comparison tests. Non-significant differences between subhabitat types for the Laurencia data are $p=0.051$. 
Plocamium

\begin{tabular}{cccccc}
\hline $\begin{array}{c}\text { SOURCE OF } \\
\text { VARIATION }\end{array}$ & SS & DF & MS & F-RATIO & P \\
\hline DATE & 4.68 & 2 & 2.34 & 9.53 & $<<0.01$ \\
SUBHABITAT & 14.67 & 2 & 7.33 & 29.87 & $<<0.01$ \\
DATE^SUBHABITAT & 1.72 & 4 & 0.43 & 1.75 & 0.147 \\
ERROR & 19.89 & 81 & & & \\
\hline
\end{tabular}

Tukey Multiple Comparison Results:

Subhabitat: Open Pterygophora Vertical

*all differences significant $(p<0.05)$

Date: Fall 92 Spring 93 Summer 93

\begin{tabular}{cccccc}
\multicolumn{7}{c}{ Laurencia } \\
\hline $\begin{array}{c}\text { SOURCE OF } \\
\text { VARIATION }\end{array}$ & SS & DF & MS & F-RATIO & P \\
\hline DATE & 2.40 & 2 & 1.20 & 1.81 & 0.17 \\
SUBHABITAT & 15.0 & 2 & 7.50 & 11.29 & $<<0.01$ \\
DATE*SUBHABITAT & 0.4 & 4 & 0.10 & 0.15 & 0.96 \\
ERROR & 53.8 & 81 & 0.66 & & \\
\hline
\end{tabular}

Tukey Multiple Comparison Results:

Subhabitat: Open Pterygophora Vertical 
Table 4. One-way analysis of variance on the effects of subhabitat type on the frequency of permenant settlement of Plocamium fragments to artificial coralline mats. A Tukey multiple comparison test showed significant differences between all subhabitat types. 


\begin{tabular}{|c|c|c|c|c|}
\hline $\begin{array}{l}\text { SOURCE OF } \\
\text { VARIATION }\end{array}$ & $\overline{D F}$ & MS & F-RATIO & $\mathbf{P}$ \\
\hline $\begin{array}{l}\text { SUBHABITAT } \\
\text { ERROR }\end{array}$ & $\begin{array}{c}2 \\
23\end{array}$ & $\begin{array}{l}2.68 \\
0.20\end{array}$ & 13.19 & $<0.001$ \\
\hline $\begin{array}{l}\text { OPEN }>1 \\
0.91\end{array}$ & $\begin{array}{r}\text { GO } \\
0 .\end{array}$ & & $\begin{array}{l}\text { JERTIC/ } \\
0.17\end{array}$ & \\
\hline
\end{tabular}


Figure 1. Branching morphologies in Plocamium cartilagineum from Stillwater Cove: Robust or incurved morphology $(A)$ and hooked or outcurved morphology (B). The two terminal branchlets were taken from different ramets on the same plant. 


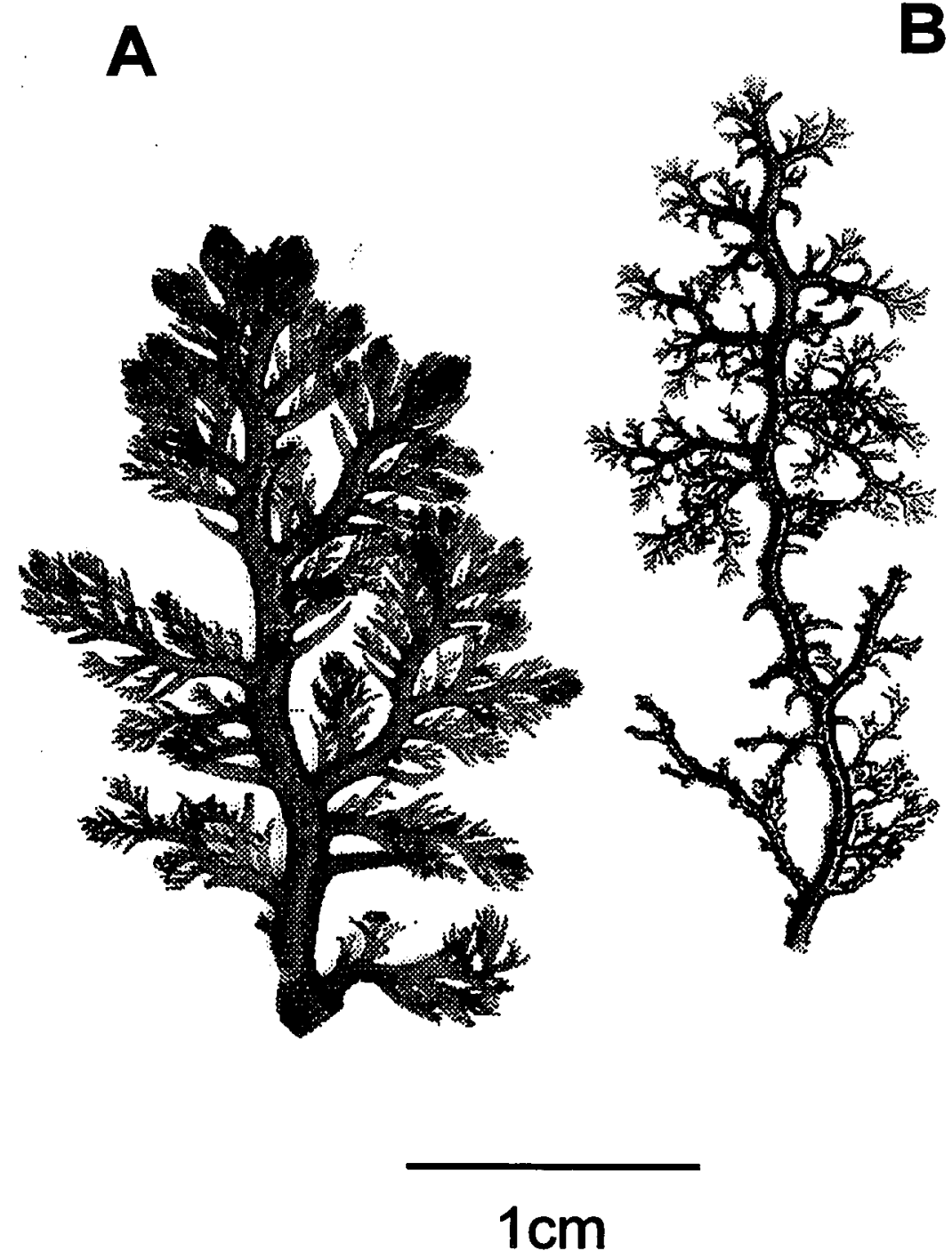


Figure 2. Proportion of each sample grouped by degree of spore release. Cystocarpic plants at $2 \mathrm{~m}$ site were classified by size of cystocarps. The classes for tetrasporic plants were: not reproductive, immature stichidia with no pigmented tetraspores, fully formed tetraspores $<50 \%$ released, between 50 and $75 \%$ released, and $>75 \%$ released. The classes for cystocarpic plants were: not reproductive, cystocarps just emergent as small bumps, fully formed to $1 \mathrm{~mm}$, unreleased larger than $1 \mathrm{~mm}$, and empty or released. The ratios of fertile cystocarpic to tetrasporic plants for each date are shown above the $2 \mathrm{~m}$ graph. $\mathbf{N}=30$ plants for each date. Samples were collected quarterly at 2 and $30 \mathrm{~m}$ and monthly at $15 \mathrm{~m}$. $\mathrm{N}=30$ for each collection at each site. 

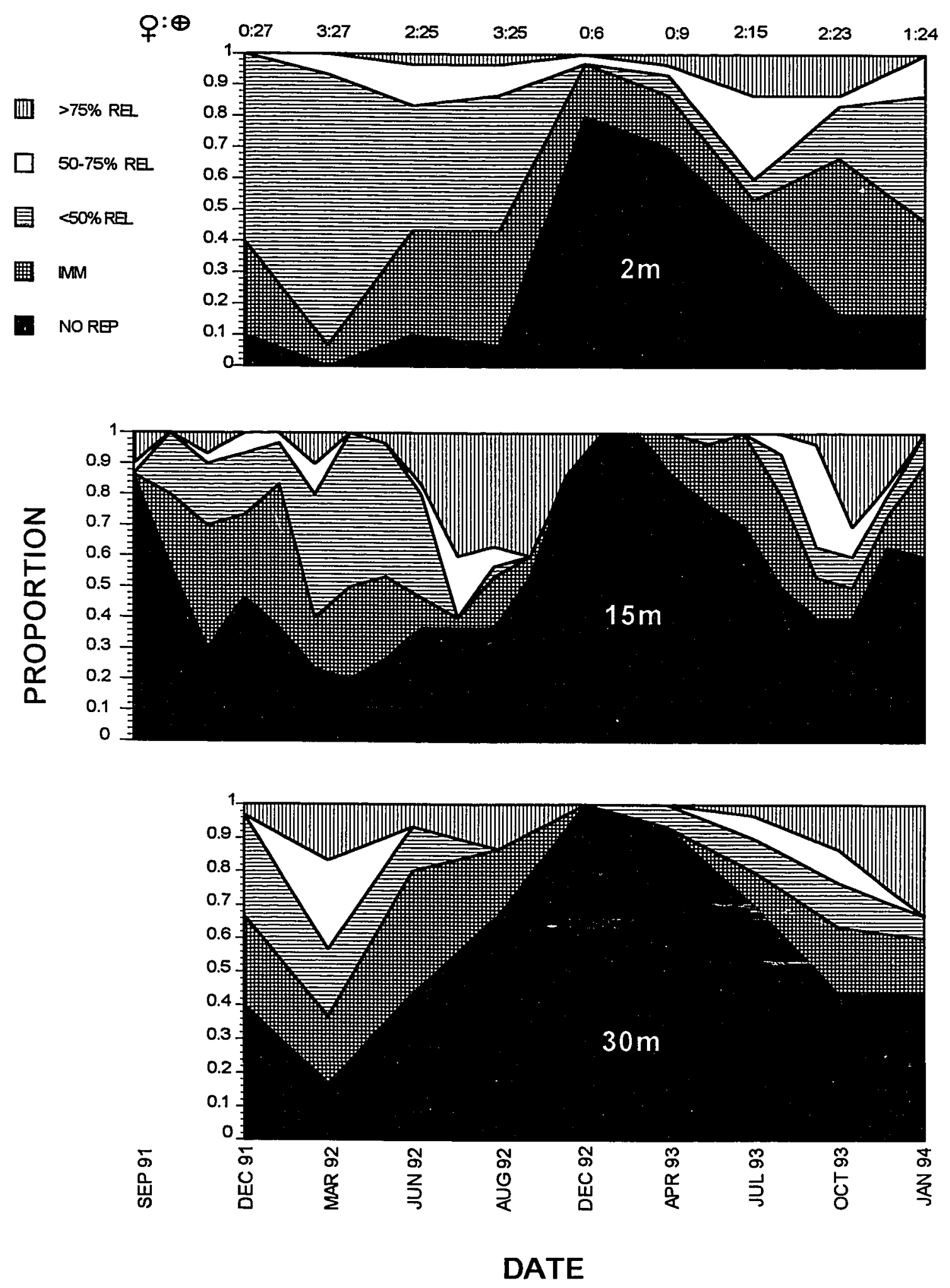
Figure 3. (A) Mean number of plants per transect $(+/-S E, n=3)$ with the hooked morphology. (B) Mean dry weight $(+/-S E, n=30)$ by collection date. (C) Mean $+/-$ $\mathrm{SE}, \mathrm{n}=30$ ) longest length of the plocamium plants at each site. Plants were measured from the stolon complex to the end of the longest branch. " $A$ " reflects a significant $(p<0.05)$ difference between the 2 and $15 \mathrm{~m}$ sites, " $B$ " between 2 and $30 \mathrm{~m}$ sites, and " $C$ " between 15 and $30 \mathrm{~m}$ sites. Differences between sites on dates with no letter are not significant. 

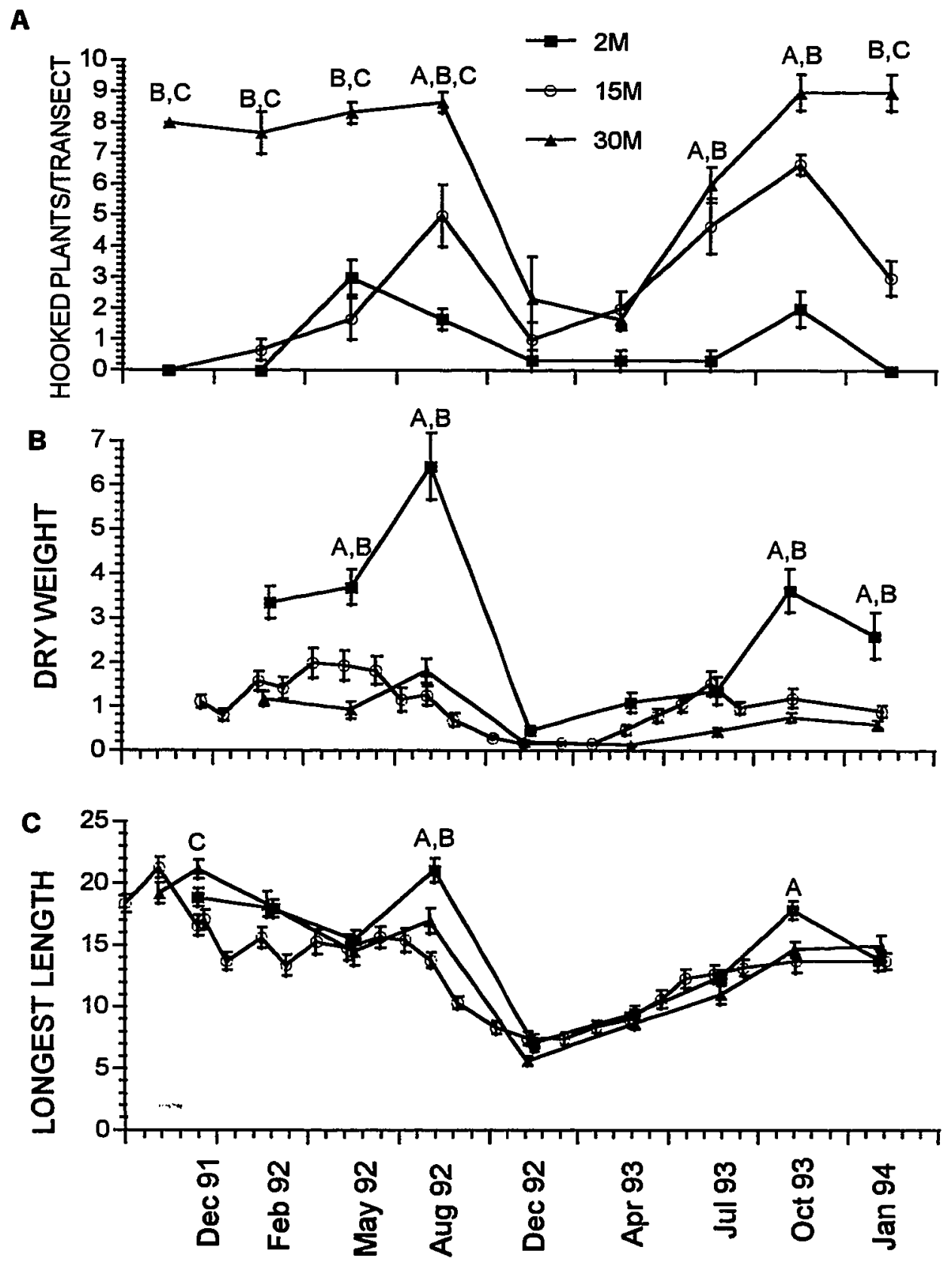

COLLECTION DATE 
Figure 4. Mean number of fragment recruits on each treatment type by interval. The winter data set was omitted due to damaged experimental apparatus. $N=10$ in all cases but Spring '93, where two replicates were lost from the vertical treatment. 


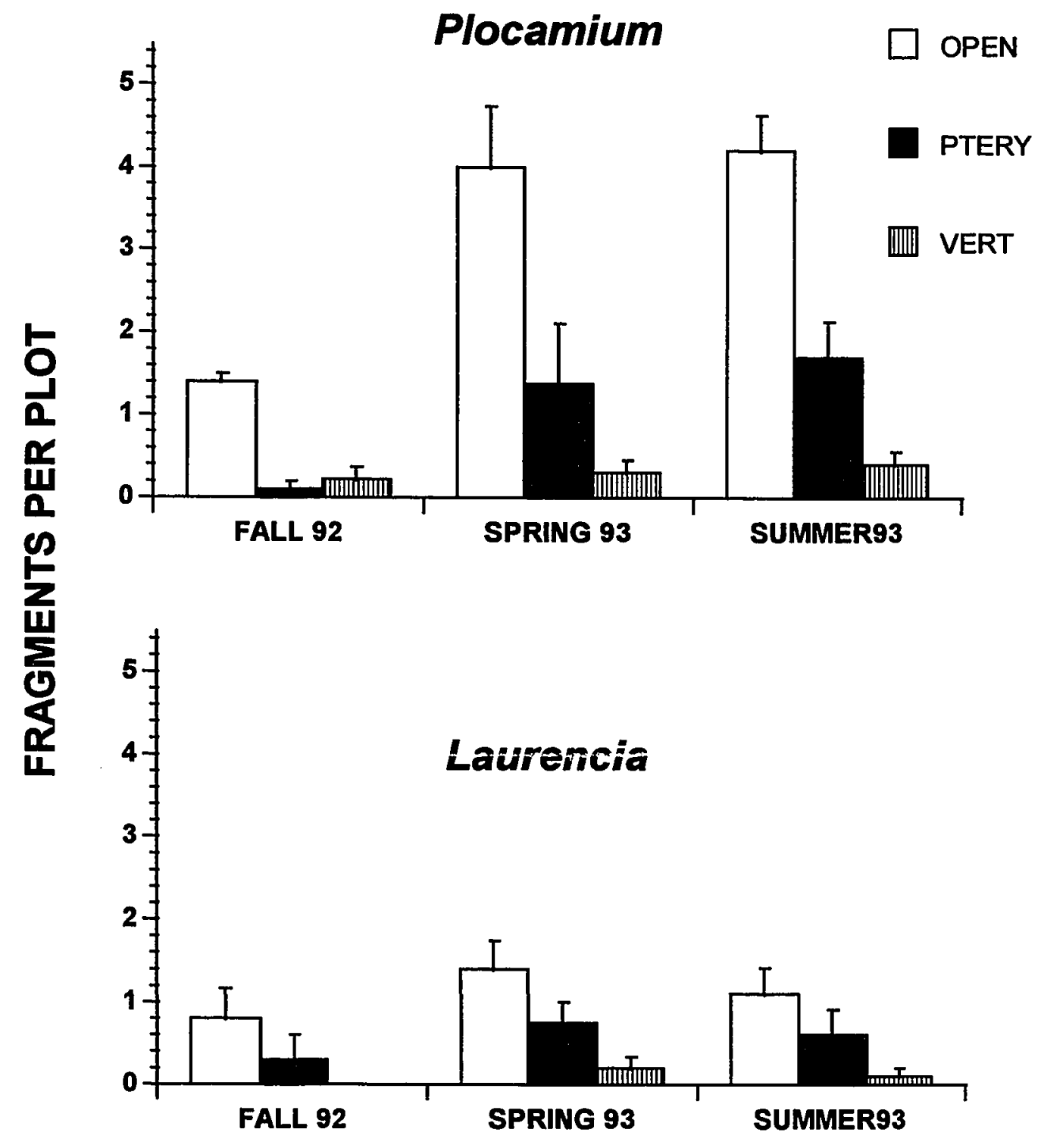

